\title{
Laryngeal Undifferentiated Carcinoma
}

National Cancer Institute

\section{Source}

National Cancer Institute. Laryngeal Undifferentiated Carcinoma. NCI Thesaurus. Code C54339.

An undifferentiated carcinoma that arises from the larynx. This category includes lymphoepithelial carcinoma and giant cell carcinoma. 